\title{
Editorial
}

\section{Comparing biological effects of mineral fibres}

Careful examination of the great majority of in vitro and in vivo experimental protocols to assess the biological effects of mineral fibres shows that comparison of the effects (in vitro cytotoxicity, fibrogenicity, and tumour yield) has traditionally been based on a gravimetric basis - that is, by comparing the effects produced by equal mass of tested minerals-for example, $50 \mu \mathrm{g} / 10^{5}$ cells; $20 \mathrm{mg}$ dose by intraperitoneal injection; $20 \mathrm{mg} / \mathrm{m}^{3}$ by inhalation, etc).

The effects reported are often not consistent with epidemiological observations. In recent years the development of sophisticated techniques for tissue mineral analysis has led to some possible explanations for the inconsistencies between animal experimental data and epidemiological evidence, pointing to the different durability of mineral fibres and their different relative lifespan persistence between laboratory animals and man.

We consider that another explanation may also reside in the basis for reporting the observed effectsthat is, equal mass $v$ equal number of fibres.

Contrary to experimental-data, human experience of exposure to different asbestos fibre types and manmade mineral fibres has shown an impressive difference in pathological potency, chrysotile being much less fibrogenic and carcinogenic, and having little mesothelioma producing potential (if at all) compared with amphiboles. Recently, Wagner et al wrote, "We believe therefore that chrysotile is the least harmful form of asbestos in every respect and that more emphasis should be laid on different biological effects of amphibole and serpentine asbestos fibre."1

Recently, manmade mineral fibres, especially rock/ slag wools, have been positively correlated with excess incidence of lung cancer in production workers at low exposure levels, indeed at exposure levels $(\sim 1 \mathrm{f} / \mathrm{ml})$ where chrysotile has been shown to produce no excess lung cancer. There is some uncertainty about the estimates of exposure in the early production phase of rock/slag, and there may have been additional contributing factors such as the presence of polycyclic aromatic hydrocarbons or arsenic to the reported excess lung cancer mortality; all these sources may have contributed to the observed hazard, but as Doll said at the 1986 Copenhagen Symposium ". . . none has produced a quantitatively similar hazard elsewhere, unless exposure was both intense and prolonged."2

The problem is that despite the human data, some regulatory agencies such as the United States Environ- mental Protection Agency maintain that chrysotile has the same potential as the other asbestos fibre types, and that manmade mineral fibres have lower pathogenic potential based on animal experiments using equal mass doses.

Limited attempts to transform retrospectively gravimetric doses into fibre number-doses have indicated that if based on fibre number the pathogenicity would show that "fibre for fibre" chrysotile would be seen as less potent than the other asbestos fibre types, and possibly some other manmade mineral fibres as well. For instance, Davis et al have reported that rats submitted to dust clouds of chrysotile, crocidolite, and amosite showed more lung fibrosis and tumours after inhalation of chrysotile than with either amphiboles. ${ }^{3}$ But, they state: ". . . it was found that the chrysotile dust clouds used in this study contained many more fibres longer than 20 microns than either of the amphibole dust clouds."

In 1986, Peto, using animal data from Wagner, ${ }^{4}$ analysed the effects per fibre rather than per unit mass relevant to the comparison of asbestos and manmade mineral fibres in the induction of pulmonary tumours by inhalation. The results shown in the table indicate that a similar mass of chrysotile produced a greater incidence of tumour than manmade mineral fibres but that the risk per fibre may have been similar for chrysotile and glass wool, and possibly greater for rock wool. (All groups had been exposed to $10 \mathrm{mg} / \mathrm{m}^{3}$ but the fibre count was more than 10 times higher for chrysotile than for rock wool or glass wool.) While there is some scepticism in the scientific community about such retrospective analysis, it would be most desirable to have more relevant experimental data.

Also in 1986 Goldsmith indicated that "based on fibre or particle counts, manmade mineral fibres appear to be more potent than asbestos with regard to chronic pulmonary disease."

Finally, in a more recently published in vitro study on the comparison of mass $v$ number of fibres in the cytotoxic response of Chinese hamster lung V79 cells to erionite, crocidolite, and chrysotile, especially for fibres $\mathrm{L}>8$ microns, $\mathrm{W}<0.25$ microns, the UICC chrysotile fibres emerge as the least potent. ${ }^{6}$ Their data show that both samples of erionite required fewer fibres than UICC crocidolite, and that UICC chrysotile required a significantly higher number of fibres than the other three tested materials to produce similar cytotoxicity. For instance, the $\mathbf{L D}_{50}$ values (in fibre number) for V79 cytotoxicity shows the follow- 


\begin{tabular}{|c|c|c|c|c|c|c|c|}
\hline Material (no of rats) & $\begin{array}{l}B A H^{*} \\
(a)\end{array}$ & $\begin{array}{l}\text { Adenoma } \\
\text { (b) }\end{array}$ & $\begin{array}{l}\text { Adenoma } \\
\text { (c) }\end{array}$ & $\begin{array}{l}\text { Adeno- } \\
\text { carcinoma } \\
\text { (d) }\end{array}$ & $\begin{array}{l}\text { All } \\
\text { neoplasms } \\
(b+c+d)\end{array}$ & $\begin{array}{l}\text { Average } \\
\text { cumulative } \\
\text { dose per rat } \\
\text { at } 12 \text { months }\end{array}$ & $\begin{array}{l}\text { Tumours per } \\
\text { l00 fibres } / \mathrm{cm}^{3} \\
\times h\end{array}$ \\
\hline $\begin{array}{l}\text { UICC chrysotile (48) } \\
\text { Glass microfibre (48) } \\
\text { Rock wool (48) } \\
\text { Glass wool with resin (48) } \\
\text { Glass wool resin free (47) } \\
\text { Controls (48) }\end{array}$ & $\begin{array}{l}5 \\
3 \\
1 \\
3 \\
1 \\
1\end{array}$ & $\begin{array}{l}0 \\
0 \\
1 \\
0 \\
1 \\
0\end{array}$ & $\begin{array}{l}1 \\
0 \\
1 \\
0 \\
0 \\
0\end{array}$ & $\begin{array}{r}11 \\
1 \\
0 \\
1 \\
0 \\
0\end{array}$ & $\begin{array}{r}12 \\
1 \\
2 \\
1 \\
1 \\
0\end{array}$ & $\begin{array}{r}656 \\
223 \\
39 \\
55 \\
41 \\
-\end{array}$ & $\begin{array}{l}1 \cdot 8 \\
0 \cdot 4 \\
5 \cdot 1 \\
1 \cdot 8 \\
2 \cdot 4 \\
-\end{array}$ \\
\hline
\end{tabular}

*Bronchoalveolar hyperplasia.

†Benign.

tSome features of malignancy.

SFibres $/ \mathrm{cm}^{3}$.

Note: This table is reproduced from "Request from HSE for an opinion on the carcinogenic potential of glass fibre, glass wool, slag wool and rock wool. A resume of the revelant biological properties" which was prepared for the Committee on carcinogenicity.

ing: erionite samples: $\sim 1 \cdot 1 \times 10^{5}$; crocidolite: $6.28 \times 10^{5}$; chrysotile: $348.8 \times 10^{5}$. For fibre lengths equal to or smaller than 5 microns the difference is even more pronounced. These observations do not rule out other important factors in possible reasons for a gradient in fibre potency, such as chemical differences in fibre types, durability (persistence in tissues), and possibly others. For a similar mass, a sample with a higher number of fibres would also have a larger surface area than a sample with lower fibre number.

At present, TLVs for asbestos fibre types are in fibre numbers almost everywhere, whereas gravimetric standards (from $\sim 5$ to $10 \mathrm{mg} / \mathrm{m}^{3}$ ) are still the current rule for manmade mineral fibres in many countries, although some national regulatory authorities have recently adopted standards in fibre numbers. Thus it will be interesting to follow up the developments and to watch how TLVs for manmade mineral fibres will eventually compare with each asbestos fibre type.

Meanwhile, carefully planned animal experimentation, where doses are measured in fibre numbers, and where results are expressed in effects//fibre number, would certainly help to support the contention that if chrysotile must be controlled to low levels such as $1 \mathrm{f} / \mathrm{ml}$, manmade mineral fibres must also be controlled at the same levels (and possibly lower levels in the case of rock wool). The manmade mineral fibres, as well as the refractory (ceramic) fibres, are used/ proposed as asbestos substitutes in many applications including friction materials, thermal insulation, fibre reinforced plastics and resins, and gaskets and joints.

\section{Current status of regulation for manmade mineral fibres}

Regulations governing exposure to manmade mineral fibres in many countries are still based on gravimetric measurements, from $\sim 5$ to $10 \mathrm{mg} / \mathrm{m}^{3}$. Sweden and Poland, however, have now turned to fibre number $(2.0 \mathrm{f} / \mathrm{ml})$, and Denmark, Norway, and Sweden are considering a TLV of $1.0 \mathrm{f} / \mathrm{ml}$. Superfine manmade mineral fibres are classified as a "suspected carcinogen" by Austria and the USSR, and are strictly regulated in the United Kingdom with a TLV of $1.0 \mathrm{f} / \mathrm{ml}$. In the United States the Occupational Safety and Health Administration is considering a recom- mendation of $3 \mathrm{f} / \mathrm{ml}$ made by the National Institute fo 9 Occupational Safety and Health. Methods for fibre counts are already available. The ISO has published $\$$ proposed method (Determination of the number $\overrightarrow{0} \vec{\Phi}$ airborne inorganic fibres by phase contrast opticas microscopy-membrane filter method) which is expec-ted to be officially adopted in 1989 or 1990 . $^{\text {The }}$ WHO/Regional Office for Europe/Copenhagen has also published a reference method for measuring airborne manmade mineral fibres. ${ }^{8}$

It seems therefore that the stage is set for am increasing trend away from gravimetric data to fibre. counts, and that if TLVs are to be expressed in fibre numbers per unit volume of air such TLVs shouldobe based on scientific data which are reported on the basie of fibre number rather than on a mass basis.

Science Faculty, J DUNNIǴĀ University of Sherbrooke, Sherbrooke, Quebec, Canada JIK 2RI.

\section{References}

1 Wagner JC, Newhouse ML, Corrin B, Rossiter CER, Griffithis DM. Correlation between fibre content of the lung and disease in East London asbestos factory workers. $\mathrm{Br} J$ Ind $\mathrm{Med}$ 1988;45:305-8.

2 Doll R. Manmade mineral fibres in the working environment Proceedings of international symposium. Ann Occup $H \vec{y}$. 1987;31:805-17.

3 Davis JMG, Beckett ST, Bolton RE, Collings P, Middleton AP Mass and number of fibres in the pathogenesis of asbestos related disease in rats. $\mathrm{Br} J$ Cancer 1978;37:673-88.

4 Wagner JC. Health hazards of substitutes. In: Proceedings of the world symposium on asbestos, Montreal, 1982. Montreat Canadian Asbestos Information Center, 1982:244-66.

5 Goldsmith JR. Comparative epidemiology of men exposed tक्ष asbestos and man-made mineral fibers. Am $J$ Ind Med 1986;10:543-52.

6 Palekar LD, Most BM, Coffin DL. Significance of mass andu number of fibers in the correlation of V79 cytotoxicity with tumorigenic potential of mineral fibers. Environ Res 1988;46:142-52.

7 International Organisation for Standardisation. Determination the number concentration of airborne inorganic fibres by phase contrast optical microscopy-membrane filter method. Genevä: ISO, 1986. [Doc ISO OP8672/WP5.)

8 World Health Organisation. Reference method for measurin airborne man-made mineral fibres. Copenhagen: WHO 198\$ (HE4.) 